\title{
Modern Conducted Labor is Medically Assisted
}

\author{
Mirjana B. Prvulović, Danijela O. Rodić
} Clinical Centre "Dr Dragiša Mišović, Dedinje”, Hospital for Gynecology and Obstetrics; Bel-
grade, Serbia

\section{SUMMARY}

Introduction: First child delivery stage lasts $12-16$ hours not including any medications, while the second child delivery stage and grand multiparity last a couple of hours shorter. Oxytocin (Syntocinon ${ }^{\circledR}$ ) is drug that facilitates well-fed delivery, therefore, induced labor assisted by peridural lasts approximately 4 hours less than natural labor not supported by any medication.

Aim: To make quantitative analysis of the medically assisted childbirth and spontaneous vertex delivery within three years (2014-2016).

Methodology: This paper is part of a non-commercial, retrospective, IV phase epidemiological study. The study was conducted at the Clinical Centre "Dr Dragiša Mišović, Dedinje", Hospital for Gynecology and Obstetrics. The data are obtained from the ZS Monthly-Yearly Heliant Reports of the Hospital for Gynecology and Obstetrics, Delivery room.

Results: In the Clinical Centre "Dr Dragiša Mišović, Dedinje", Hospital for Gynecology and Obstetrics, Delivery room there is over 2000 childbirths annually. Number of pharmacologically assisted labors was 1290 or (62\%) in 2014, in 2015 was 1318 or (61\%) and in 2016 was 1286 or $(60 \%)$. Using syntocinon, there was 585 or $(28 \%)$ in 2014 , in 2015,513 or $(28 \%)$ and in 2016,639 or $(30 \%)$ cesarean sections, urgent, planned and elective labors. Of the total $80 \%$ of newborns received Apgar score 9 (nine).

Conclusions: Labor induced by medication is a joint choice of a midwifes and doctors health team because the flow of labor can be anticipated and influenced at any moment.

Keywords: delivery, oxytocin, pharmacology supported, midwife, gynecologist

\section{INTRODUCTION}

Obstetrician prescribes the therapy while the nurse-midwife applies it, as in any other case in medical field. Oxytocin (Syntocinon ${ }^{\circ}$ ) solution for injection / concentrate solution for infusion; 5 i.j./ml; 10 i.j./ml, Novartis Pharma Stein AG) is a synthetic nonapeptide, identical to oxytocin, which is a natural hormone of the pituitary gland rear lobe. It affects smooth uterus muscles and causes their contraction, and due to this fact, it is mostly used in obstetrics $[1,2,3]$. As any other drug, it has its own indications and contraindications (table 1).

First child delivery stage lasts 12-16 hours not including any medications, while the second child delivery stage and grand multiparity last a couple of hours shorter [4]. Syntocinon is drug that facilitates well-fed delivery, therefore, induced labor assisted by 
Oxytocin

- induction of childbirth with a clear medical indication;

- labor stimulation in individual cases poor contractions of the uterus;

therapeutic indications

- during cesarean section, after childbirth and placental removal; -prevention and therapy of postpartum uterine hemorrhage and uterine atony -in early stages of pregnancy, as an adjuvant therapy in cases of incomplete, preterm or spontaneous abortion.

- oxytocin-susceptibility or any of the other substances included in the drug. - hypertonic contraction of the uterus, mechanical childbirth obstruction, fetal distress.

- any condition due to the safety of the mother or fetus spontaneous childbirth is not advised

contraindications and / or the vaginal childbirth is contraindicated: significant cephalopelvic disproportion, fetal malpresentation, placenta previa or vasa previa, placenta abruption, prolapse or presentation of the umbilical cord, excessive stretching of the uterus and reduced uterine resistance to rupture as in multiple pregnancies, ), excessive fetal water, in women with a large number of previous grand multiparity, in the presence of scarring on the uterus as a result of extensive surgical interventions, including cesarean section.
Table 1. Oxytocin therapeutic indications and contraindications peridural lasts approximately 4 hours less than natural labor not supported by any medication [5]. More than $50 \%$ of labors are completed by administering some drug because this way can be obtained the necessary strength and the contraction interval, and it is easier and quicker for the mother to pull through certain stages.

Induced labor is influenced by medication or some kind of obstetric intervention. In the Republic Health Insurance Fund (RHIF) classification, these services can be described with fallowing multiple codes [6-8]:

90466-01 (90466-01) - Actively induced childbirth with obstetric intervention

90466-02 (90466-02) - Inducing childbirth with medical and obstetric interventions 90465-00 (90465-00) - Induction of oxytocin childbirths

90465-01 (90465-01) - Induction of prostaglandin childbirths

90469-00 (90469-00) - Completing the childbirth by vacuum extraction

90470-01 (90470-01) - Pelvic childbirth with manual assistance

16520-02 (16520-02) - Elective Cesarean section with incision on the lower segment of the uterus

16520-03 (16520-03) - Urgent Cesarean section with incision on the lower segment of the uterus

Natural childbirth isn't influenced either by medication or by any obstetric intervention during the first three stages. In the RHIF service classification [6-8] it's described as following:

90467-00 (90467-00) - Spontaneous labors

The most common usage of Syntoci- non is for the induction or stimulation of contractions.

Induction involves 5IJ Syntocinon in a $500 \mathrm{ml} 0.9 \% \mathrm{NaCl}$ solution $24 \mathrm{ml} / \mathrm{h}$, therefore, it can be increased by half an hour. Naturally, obstetrician prescribes the therapy after pregnant woman examination [1].

In stimulation, it starts with the completely same therapy, but dose of $\mathrm{ml} / \mathrm{h}$ is given after the gynecological examination, because it indicates labor stage, the extent of dilatation, while cardiotocography (CTG) shows contraction strength level [1].

In expulsion Syntocinon is used when contraction tensions are absent or stopped and patient needs help at the final stage. Syntocinon is then administered in a bolus of $5 \mathrm{IU}$ in $20 \mathrm{ml}$ $\mathrm{NaCl}$ of $0.9 \%$ per $1 \mathrm{ml}$ or $2 \mathrm{ml}$, as the physician prescribes [1].

The induction of the labor shortens the duration of delivery, so it is also significant for the patient and for the entire team and contributes to a better outcome. Nowadays, with the help of pharmacology, more precisely, medication for well-fed delivery and medication for the elimination of pain, future mothers can finally enjoy the most precious day of life. It is very important for midwives that the patients suffer less from the pain and that delivery lasts shorter so when the expulsion occurs, they have better cooperation with the mother. Consequently, the outcome of the labor is much more favorable and the Apgar scores i.e. the evaluation of newborns are much better.

\section{AIM}

To make quantitative analysis of the medically 
assisted childbirth and spontaneous vertex delivery within three years (2014-2016).

\section{METHODOLOGY}

This paper is part of a non-commercial, retrospective, IV phase epidemiological study. The study was conducted at the Clinical Centre "Dr Dragiša Mišović, Dedinje", Hospital for Gynecology and Obstetrics.

The data are obtained from the ZIS Monthly-Yearly Heliant Reports of the Hospital for Gynecology and Obstetrics, Delivery room $[6,7]$.

\section{RESULTS}

In the Clinical Centre "Dr Dragiša Mišović, Dedinje", Hospital for Gynecology and Obstetrics, Delivery room there is over 2000 childbirths annually (Table 2).

Table 2. Total number of childbirths per year 2014-2016

\begin{tabular}{l|c|c|c|}
\multicolumn{1}{c|}{ Year } & 2014 & 2015 & 2016 \\
$\begin{array}{l}\text { TOTAL childbirths per } \\
\text { year }\end{array}$ & 2076 & 2156 & 2120 \\
\hline
\end{tabular}

Table 3. Number of spontaneous labors 2014-2016

\begin{tabular}{|c|c|c|c|}
\hline Year & 2014 & 2015 & 2016 \\
\hline $\begin{array}{l}90467-00 \quad(90467-00) \\
\text { Spontaneous labors }\end{array}$ & -1424 & 1428 & 1396 \\
\hline
\end{tabular}

Table 4. Number of pharmacologically assisted labors in 2014-2016
During 3 years, the number of spontaneous labors in vertex position, that is, in non-pharmacologically supported labors was more than 1300 (Table 3).

Approximately $1 \%$ are labors without peridural anesthesia, and over $50 \%$ of the labors are induced with the help of Syntocinon [6].

Number of pharmacologically assisted labors was 1290 or (62\%) in 2014, in 2015 was 1318 or (61\%) and in 2016 was 1286 or $(60 \%)$. Using syntocinon, there was 585 or $(28 \%)$ in 2014 , in 2015,513 or $(28 \%)$ and in 2016,639 or (30\%) cesarean sections, urgent, planned and elective labors (Table 4).

Of the total $80 \%$ of newborns received Apgar score 9 (nine), to the satisfaction of the entire team of Maternity clinic, including doctors, pediatricians, anesthetists, midwives, anesthetists and pediatric nurses [9].

\section{DISCUSSION}

Modern obstetric procedures involve safer and more comfortable childbirths.

Shortening labors of 4 and more hours lowers the trauma of the mother and the child and reduces the possibility of delivery and post-partum complications [2,3]. Today, patients are well-informed, pregnant women want to have a more comfortable, possibly pain-free modern well-fed delivery. The results of our study are in conformity with other authors, the number of pharmacologically-assisted labors is more than $80 \%$ of the total number of childbirths, i.e. labors not influenced by pharmacological or any obstetric intervention.

Conducted, modern labor helps to anticipate and influence the labor process at any moment. Syntocinon is necessary in pharmacologically-assisted labors whether it is completed operatively or vaginal. In third stage, all women that gave vaginal births receive $5 \mathrm{i}$.j. of syntocinon to facilitate the uterus contraction and the rapid stopping of bleeding.

\section{CONCLUSION}

16520-02 (16520-02) -

Elective cesarean sec-

tion with incision on

lower uterus segment

16520-03 (16520-03) -

Urgent cesarean section

with incision on lower

uterus segment
Labor induced by medication is a joint choice of a midwifes and doctors health team because the flow of labor can be anticipated and influenced at any moment. 


\section{REFERENCES}

1. Sazetak karakteristika leka. Syntocinon. Agencija za lekove I medicinska sredstva Srbije. Broj resenja 515-01-8925-12-001 i 515-01-8926-12-001 od 09.07.2013./Summary of drug characteristics. Syntocinon. Agency for Medicinal Products and Medical Devices of Serbia. No 515-01-8925-12-001 and 51501-8926-12-001 of 09. 07. 2013. (on Serbian)

https: / / www.alims.gov.rs/eng/medicinal-products/search-for-human-medicines/

2. Čutura N, Soldo V, Ćurković A. Frequency of uterine rupture at delivery and accompanying risks for the mother and the newborn. Vojnosanitetski Pregled. 2009; 66(8): 635-638. (on Serbian)

3. Westhoff G, Cotter AM, Tolosa JE. Prophylactic oxytocin for the third stage of labor to prevent postpartum hemorrhage. Cochrane Database of Systematic Reviews 2013, Issue 10. Art. No.: CD001808. DOI: 10.1002/14651858.CD001808.pub2

4. Bogdanović Z, Mladenović-M A, Mladenović D Ginekologija i akušerstvo / Gynecology and Obstetrics, ISBN 978-86-17-15671-6, IX izdanje / edition 2008. (on Serbian)

5. Academy of sciences and arts of Bosnia and Herzegovina Department Medical sciences Advancement in Gynecology and Obstetrics. DizdarevićStojkanović J, Stojkanović G. Savremena terapija hipertenzivnih bolesti u trudnoći proceedings / Modern therapy of hypertensive diseases in pregnancy proceedings: Volume 44; 50-61 Sarajevo, novembar 2012. DOI 10.5644/PI2014-156-04. (On Serbian)

http://www.anubih.ba/images/publikacije/posebna_izdanja/OMN/32_posebna_izdanja_CLVI_44.pdf

6. ZIS Heliant-Zdravstveni informacioni sistem (v7.0) : Bolnički izveštaji: mesečni / godišnji / ZIS Heliant-Health Information System (v7. 0): Hospital reports: monthly / annual (on Serbian ).

7. RFZO Širarnik usluga 09.02.2015. 222 / RHIF Service Codebook 09. 02. 2015. 222

http://www.kcnis.rs/files/fakturisanje_info/sifarnici/Usluga_09_02_2015.pdf

8. RFZO Širarnik lekova B lista 05.10.2017. $20 /$ RHIF Drugs Codebook B List 05. 10. 2017. 20 (on Serbian)

http: //rfzo.rs/download/pravilnici/lekovi/ Lista\%20B_primena\%20od\%2005.10.2017..pdf

9. Protokol porođaja KBC “Dr Dragiša Mišović, Dedinje” , Bolnica za ginekologiju i akušerstvo / Labor protocol Clinical Centre "Dr.Dragisa Misovic, Dedinje “ , Hospital for Gynecology and Obstetrics (on Serbian). 


\section{Savremeno vođeni porođaj je medikamentozno potpomognut}

Mirjana B. Prvulović, Danijela O. Rodić

Klinički centar “Dr Dragiša Mišović, Dedinje”, Bolnica za ginekologiju, Odeljenje porodiliste; Beograd, Srbija

\section{KRATAK SADRŽAJ}

Uvod: Porođaj prvorotke traje od $12-16$ sati kada se ne dodaju nikakvi medikamenti, kod drugorotki i viserotki traje par sati kraće. Oxytocin (Syntocinon ${ }^{\circledR}$ ) je lek koji nam omogućava lakše vođenje porođaja, te dirigovani porođaj potpomognut periduralom traje i po $4 \mathrm{~h}$ kraće od prirodnog porođaja ne potpomognutim medikamentozno. Više od $50 \%$ porođaja se završi uz davanje nekog leka jer na taj način možemo dobiti jačinu i interval kontrakcija koje su potrebne, te će porodilji biti lakše i brže da prođe kroz određene faze.

Cilj: Cilj ovoga rada je numericka/kvantitativna analiza vodjenja porodjaja medikamentozno i spontatog temenog porodjaja tokom tri godine (2014-2016).

Metodologija: Ovaj rad je deo nekomercijalne, retrospektivne, epidemioloske studije, IV faze. Studija je sprovedena u Klinicko bolnickom centru (KBC) "Dr Dragisa Misovic", Bolnica za ginekologiju, odeljenje porodilista (Delivery room). Podaci su dobijeni iz ZIS Heliant izveštaji Bolnice za ginekologiju i akušerstvo Odeljenje Porodilišta mesečni-godišnji.

Rezultati: U porodilistu KBC “Dr Dragiša Mišović-Dedinje” je godišnje preko 2000 porođaja. Porođaja na koje smo pomogli farmakološki u 2014. god bilo je 1290 ( 62\% ); u 2015. god bilo je 1318 ( 61\% ); u 2016. god bilo je 1286 ( 60\% ). Porođaja završenih carskim rezom (SC) - hitnim i elektivnim planiranim, gde takođe koristimo Sy, u 2014. god bilo je 585 (28\%); u 2015. god 513 (28\%); u 2016. god 639 (30\%). Apgar skor 9 (devet) dobilo je $80 \%$ novorođenčadi.

Zaključak: Dirigovan porođaj, porođaj potpomognut medikamentozno, je zajednicki izbor zdravstvenog tima - babica i lekar, i pacijenta - porodilje, jer u svakom momentu možemo predvideti i uticati na tok porođaja.

Ključne reči: porođaj, oxytocin, farmakološki potpomognut, babica, ginekolog 